Revista Eletrônica Geografar, Curitiba, v. 2, Resumos do VI Seminário Interno de Pós-Graduação em Geografia, p. 19-19. Junho/2007

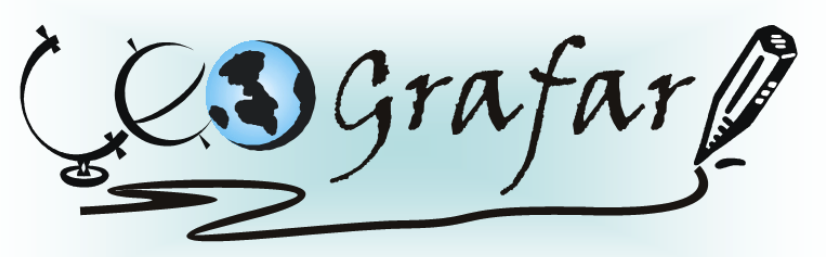

Revista Eletrônica do Programa de Pós-Graduação em Geografia - UFPR

\title{
TRANSFORMAÇÕES LOCAIS DAS RELAÇÕES SOCIAIS NUM PATRIMÔNIO DA HUMANIDADE - O CASO DA QUEBRADA DE HUMAHUACA, JUJUY/ARGENTINA
}

\section{DENISE SCHULER ${ }^{1}$}

A declaração de Patrimônio Mundial concedida pela UNESCO representa a preservação de um patrimônio de valor universal excepcional para a humanidade, com vistas à sua transmissão para as futuras gerações. Na maioria dos bens materiais tombados, porém, o título tem sido percebido também como sinônimo de desenvolvimento econômico e social. Dessa forma, implica uma decisão ideológica, política e social a respeito da apropriação e mercantilização dos bens materiais e simbólicos protegidos. Neste estudo de caso objetivase pesquisar as transformações sociais na Quebrada de Humahuaca, localizada na província de Jujuy, Noroeste da Argentina. Esta recebeu o título de paisagem cultural da humanidade pela UNESCO em 2003 por representar um sistema patrimonial de características excepcionais. Neste lugar a interação entre o sistema natural-ambiental e as sociedades e culturas andinas é visto como testemunha das atividades de ocupação humana sustentáveis, com as suas modalidades tradicionais de produção da paisagem, tecnologias, estilos construtivos, tradições e crenças, ao longo de mais de 10.000 anos de história. Hoje, porém, o que se percebe na Quebrada, é uma distância acentuada entre o discurso protecionista da e as suas conseqüências práticas, principalmente para a população local, implicando em grandes inversões sociais da preservação. Se, por um lado, relaciona-se a proteção da Quebrada aos efeitos simbólicos da memória coletiva de seu povo, aos valores dos grupos sociais e economia local, por outro lado, percebe-se uma articulação negativa entre a política de preservação e o consumo do lugar através do uso e apropriação por distintos grupos e interesses sociais externos. Nesse sentido, pretende-se discutir as contradições e desigualdades que as relações sociais assumem na declaração e no uso do patrimônio, resultando em interações complexas entre agentes internacionais, Estado, setor privado, e diferentes grupos e movimentos sociais e culturais locais. Porque e para quem se preserva a Quebrada de Humahuaca?

Palavras-chave: patrimônio, cultura, relações sociais

${ }^{1}$ Mestrando em Geografia - UFPR - email:denise_schuler@fag.edu.br Orientador: WOLF-DIETRICH SAHR 